\title{
Drying kinetics and physical and chemical characterization of white-fleshed 'pitaya' peels
}

\author{
Francislaine S. dos Santos ${ }^{1}$, Rossana M. F. de Figueirêdo ${ }^{1}$, \\ Alexandre J. de M. Queiroz ${ }^{1} \&$ Dyego da C. Santos ${ }^{1}$ \\ ${ }^{1}$ Universidade Federal de Campina Grande/Centro de Tecnologia e Recursos Naturais/Unidade Acadêmica de Engenharia Agrícola. Campina Grande, \\ PB. E-mail: suelia_santos@hotmail.com; rossana@deag.ufcg.edu.br; alexandrejmq@gmail.com (Corresponding author); dyego.csantos@gmail.com
}

Key words:

Hylocereus undatus

dehydration

mathematical modeling

betalains

\begin{abstract}
A B S T R A C T
The objective of this work was to obtain the drying kinetic curves of white-fleshed 'pitaya' peels and characterize the obtained powder regarding physical and chemical parameters. Different mathematical models were fitted to the experimental data of drying kinetics, considering the coefficient of determination $\left(\mathrm{R}^{2}\right)$, mean square deviation (MSD) and residual distribution as fit criteria. The peels had an initial moisture content of $93.38 \%$ (w.b.) and final moisture contents of $5.39 \%$ at temperature of $50{ }^{\circ} \mathrm{C}, 5.27 \%$ at $60^{\circ} \mathrm{C}$ and $4.40 \%$ at $70^{\circ} \mathrm{C}$. After drying, the peels were disintegrated to obtain the powders and characterized for moisture content, reducing sugars, total titratable acidity, ascorbic acid, betacyanins, betaxanthins, water activity and color, in order to evaluate the influence of temperature on the quality of powders. The Page model was the one that best fitted to the experimental data, presenting coefficient of determination higher than 0.998 , mean square deviation lower than 0.02 and random distribution of residuals. Increment in drying air temperature promoted increase of $\mathrm{pH}$, ascorbic acid, luminosity and yellowness, and reduction of moisture content, reducing sugars, acidity, betacyanins, betaxanthins, water activity and redness. Considering the retention of betalains, the drying temperature of $50^{\circ} \mathrm{C}$ is the most suitable for the production and use of 'pitaya' peel powder.
\end{abstract}

\section{Palavras-chave:}

Hylocereus undatus

desidratação

modelagem matemática betalaínas

\section{Cinética de secagem e caracterização física e química de cascas de pitaya com polpa branca}

\section{R E S U M O}

Objetivou-se com este trabalho obter as curvas de cinética de secagem das cascas de pitaya branca e caracterizar o pó obtido quanto aos parâmetros físicos e químicos. Diferentes modelos matemáticos foram ajustados aos dados experimentais de cinética de secagem, considerando-se como critério de ajuste o coeficiente de determinação $\left(\mathrm{R}^{2}\right)$, o desvio quadrático médio (DQM) e a distribuição dos resíduos. As cascas apresentaram teor de água inicial de $93,38 \%$ b.u. e final de $5,39 \%$ na temperatura de $50{ }^{\circ} \mathrm{C}, 5,27 \%$ em $60{ }^{\circ} \mathrm{C}$ e $4,40 \%$ em $70{ }^{\circ} \mathrm{C}$. Após as secagens, as cascas foram desintegradas, para a obtenção dos pós e caracterizadas quanto ao teor de água, açúcares redutores, acidez total titulável, ácido ascórbico, betacianinas, betaxantinas, atividade de água e cor, com a finalidade de se avaliar a influência da temperatura na qualidade dos pós. O modelo de Page foi o que melhor se ajustou aos dados experimentais, apresentando coeficiente de determinação maior do que 0,998 , desvio quadrático médio menor que 0,02 e distribuição aleatória dos resíduos. O aumento da temperatura do ar de secagem promoveu aumento do $\mathrm{pH}$, ácido ascórbico, luminosidade e intensidade de amarelo e a redução do teor de água, açúcares redutores, acidez, betacianinas, betaxantinas, atividade de água e intensidade de vermelho. Considerando-se a retenção de betalaínas, a temperatura de secagem de $50{ }^{\circ} \mathrm{C}$ é a mais adequada para produção e utilização das cascas de pitaya em pó. 


\section{INTRODUCTION}

'Pitaya' is a fruit belonging to the Cactaceae family, globally known as "dragon fruit". According to the species, its fruits may exhibit various features regarding shape, presence of thorns and colors of peel and pulp. The red-skinned white-fleshed fruit (Hylocereus undatus) is one of the main species with commercial potential (Lima et al., 2013), along with the species Hylocereus polyrhizus, which is red-skinned and red-fleshed (Fernandes et al., 2010).

White 'pitaya' processing to extract the pulp generates a large quantity of residues, such as peels, which can be used for the extraction of betalains (betacyanins and betaxanthins) (Liaotrakoon et al., 2013; Mello et al., 2015). Liaotrakoon et al. (2013) observed in 'pitaya' (H. undatus and H. polyrhizus) peels that the polysaccharides of the cell wall contain expressive amounts of highly water-soluble methyl-esterified pectic substances, whereas Mello et al. (2015) reported high concentrations of betalains in peels and mesocarp of pitaya (H. undatus), evidencing their potential as natural dye in food products, besides being rich in phenolic compounds and showing high antioxidant activity.

The specialized literature does not have studies on either 'pitaya' peel drying in convective dryers or effect of temperature on the concentration of betalains through this dehydration method. Bakar et al. (2013) dehydrated red 'pitaya' in spray-dryer and reported high betalain retention in the studied material.

Given the above and considering the coloring potential of agroindustrial residues, as well as their rich capacity of antioxidant activity, this study aimed to evaluate models of drying of white-fleshed 'pitaya' (H. undatus) peels at temperatures of 50,60 and $70{ }^{\circ} \mathrm{C}$ in forced-air oven and characterize the dehydrated products regarding physical and chemical parameters.

\section{Material AND Methods}

The raw material used was white-fleshed pitaya $(H$. undatus), with red peel and white pulp, at ripe stage, from Limoeiro do Norte-CE, Brazil. The fruits were transported in boxes to the laboratory, where they were manually selected, by eliminating those with physical damages or at inadequate maturation stage. The fruits were sanitized in chlorinated water $(50 \mathrm{ppm})$ for $15 \mathrm{~min}$ and, subsequently, rinsed in running water. After that, the fruits were subjected to diagonal cuts (Figure 1A), and pulps and seeds were separated from the peel. Initial moisture content of the peel was determined through the standard method of the oven at $105^{\circ} \mathrm{C}$ until constant weight (IAL, 2008). After that, the peels were cut into $6 \times 2 \mathrm{~cm}$ strips (Figure 1B), arranged on wire trays and subjected to drying in a forced-air oven at temperatures of 50,60 and $70{ }^{\circ} \mathrm{C}$ and air speed of $1.0 \mathrm{~m} \mathrm{~s}^{-1}$.

Drying kinetics, performed in triplicates, was obtained by weighing the samples at regular intervals of 5, 10,20,30 and $60 \mathrm{~min}$, until constant weight. At the end of the drying procedures, dry weights were determined, moisture ratios of the samples were calculated (Eq. 1) and the curves of moisture ratio as a function of drying time were plotted.
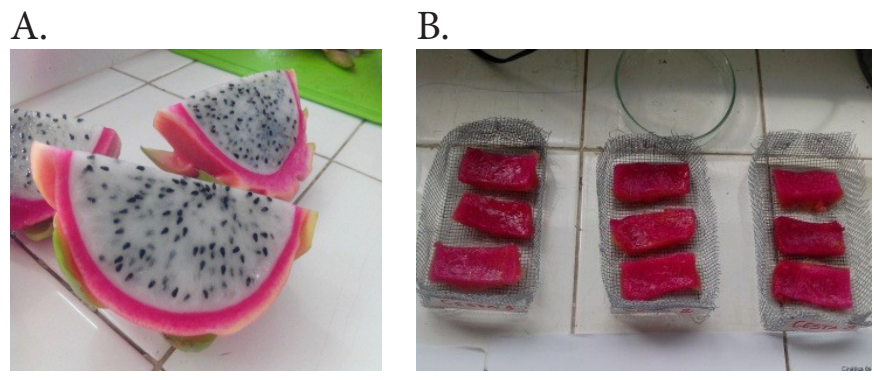

Figure 1. White-fleshed 'pitaya' (Hylocereus undatus): Fruit in diagonal cuts (A); Trays with the peels cut into strips used in the drying kinetics (B)

$$
R X=\frac{X-X_{e}}{X_{i}-X_{e}}
$$

where:

RX - moisture ratio of the product, dimensionless;

$\mathrm{X}$ - moisture content of the product, dry basis;

$X_{i} \quad$ - initial moisture content of the product, dry basis; and,

$X_{e}$ - equilibrium moisture content of the product, dry basis.

The mathematical models presented in Table 1 were fitted to the 'pitaya' peel drying kinetic curves through nonlinear regression, by the Quasi-Newton method, using the software Statistica $7.0^{\circ}$.

Table 1. Mathematical models used to estimate the 'pitaya' peel drying kinetic curves

\begin{tabular}{llc}
\hline \multicolumn{1}{c}{ Model designation } & \multicolumn{1}{c}{ Model } & Equation \\
Page & $\mathrm{RX}=\exp \left(-\mathrm{k} \mathrm{t}^{\mathrm{n}}\right)$ & $(2)$ \\
Henderson \& Pabis & $\mathrm{RX}=\mathrm{a} \exp (-\mathrm{kt})$ & $(3)$ \\
Two-term exponential & $\mathrm{RX}=\mathrm{a} \exp (-\mathrm{kt})+(1-\mathrm{a}) \exp (-\mathrm{k} \mathrm{a} t)$ \\
Logarithmic & $\mathrm{RX}=\mathrm{a} \exp (-\mathrm{kt})+\mathrm{c}$ & $(5)$ \\
Newton & $\mathrm{RX}=\exp (-\mathrm{kt})$ & $(6)$ \\
\hline
\end{tabular}

$\mathrm{RX}$ - Moisture ratio of the product, dimensionless; $\mathrm{k}$ - Drying constant; $\mathrm{a}, \mathrm{b}, \mathrm{n}$ - Coefficient of the models; $\mathrm{t}$ - Drying time, min

The best model was selected considering the coefficient of determination $\left(\mathrm{R}^{2}\right)$, mean square deviation (MSD) (Eq. 7) and residual distribution (RD). Satisfactory fit was considered as the model with high $\mathrm{R}^{2}$, close to one (1), low MSD and random $\mathrm{RD}$. $\mathrm{RD}$ is considered as random when the residuals are close to the horizontal line around zero and do not form defined figures, indicating no bias in the results. If $\mathrm{RD}$ is biased, the model is considered as inadequate (Goneli et al., 2011).

$$
\mathrm{MSD}=\sqrt{\frac{\sum\left(\mathrm{RX}_{\mathrm{pred}}-\mathrm{RX}_{\mathrm{exp}}\right)^{2}}{\mathrm{n}}}
$$

where:

MSD - mean square deviation;

$\mathrm{RX}_{\text {pred }}$ - moisture ratio predicted by the model;

$\mathrm{RX}_{\text {exp }}$ - experimental moisture ratio; and,

$\mathrm{n}$ - number of observations.

After drying, the dehydrated peels were ground in knife mill to obtain powders and characterized in quadruplicate regarding physical and chemical parameters, namely: moisture 
content through the standard method of the oven at $105^{\circ} \mathrm{C}$ until constant weight, reducing sugars through the method based on the reduction of cupric salts and cuprous oxides present in Fehling solution, total titratable acidity through the acidimetric method, titrating the sample with $0.1 \mathrm{M} \mathrm{NaOH}$ solution, and ascorbic acid through the titrimetric method, using 2,6 dichlorophenol-indophenol sodium, according to the methodologies described in the manual of IAL (2008); content of betalains (betacyanins and betaxanthins) according to Lim et al. (2011), through spectrophotometry with readings at wavelengths of 534 and $480 \mathrm{~nm}$, water activity at $25{ }^{\circ} \mathrm{C}$ through readings in Aqualab water activity meter (Model 3TE - Decagon), and color in spectrophotometer (Hunter Lab XE Plus - Model $4500 \mathrm{~L}$ ) obtaining the parameters $\mathrm{L}^{\star}$ (luminosity), $+\mathrm{a}^{*}$ (redness) and $+\mathrm{b}^{*}$ (yellowness).

The data of physical and chemical analyses were subjected to analysis of variance and means were compared by Tukey test at 0.05 probability level, in a completely randomized design with four replicates, using the software Assistat, Beta version 7.7 (Silva \& Azevedo, 2016).

\section{Results AND Discussion}

The parameters of the mathematical models fitted to the experimental data of 'pitaya' peel drying kinetics at temperatures of 50,60 and $70^{\circ} \mathrm{C}$, with the respective $\mathrm{R}^{2}$ and $\mathrm{MSD}$, as well as residual distribution (RD), are presented in Table 2 .

Among the tested mathematical models, Page showed the highest $\mathrm{R}^{2}(>0.998)$ and lowest $\mathrm{MSD}(<0.02)$ at all temperatures and was the only one to obtain random $\mathrm{RD}$ under all drying conditions, corroborating Mendonça et al. (2015), who also found that the Page model showed random RD for crabwood seeds. Goneli et al. (2011) reported that a model is considered as acceptable if the residuals exhibit random distribution. Thus, the Page model was the most adequate to represent the drying kinetics of white-fleshed 'pitaya', under all conditions evaluated.

Gonçalves et al. (2016) fitted the Page model to the data of green banana (Musa acuminata) peel and pulp drying in a forced-air oven at temperatures from 55 to $75^{\circ} \mathrm{C}$, and observed good fits to the experimental data, with $\mathrm{R}^{2}>0.99$.
The drying constant ' $\mathrm{k}$ ' of the models Page, Henderson \& Pabis, Logarithmic and Newton tended to increase with the increment of drying temperature, since higher temperatures lead to higher drying rates. The parameter ' $k$ ' represents the effect of the external drying conditions, which tends to increase as air temperature increases (Goneli et al., 2009). Similar behavior was reported by Alexandre et al. (2013) in the drying of pineapple residue at temperatures from 40 to $60^{\circ} \mathrm{C}$, evidencing that the increase in drying temperature influenced the increase of the constant ' $k$ '.

The constant ' $n$ ' in the Page model, which is related to the internal resistance of the material to drying (Perez et al., 2013), did not show a defined behavior with the increment of temperature, suggesting that external conditions have higher influence on pitaya peel dehydration. Agricultural products such as 'Mulungu' bark (Martins et al., 2014) also did not exhibit dependence between the parameter ' $n$ ' and temperature, which is consistent with the results found in the present study.

Figure 2 shows the pitaya peel drying kinetic curves fitted to the Page model. According to the set of $\mathrm{R}^{2}$ and MSD values, as well as the random residual distribution, Page was the best model to estimate pitaya peel drying under the studied experimental conditions (Table 2).

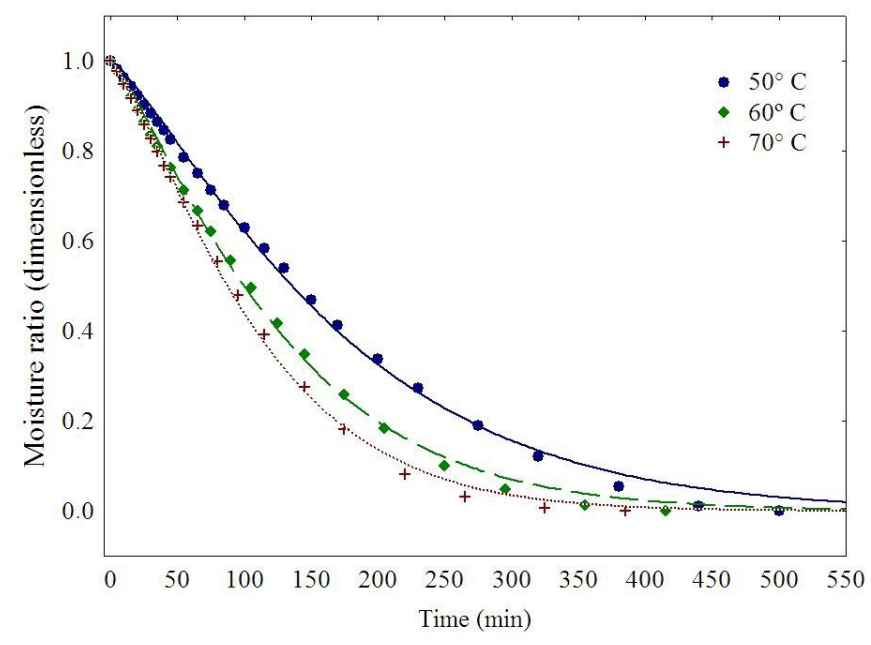

Figure 2. Pitaya peel drying kinetic curves at temperatures of 50,60 and $70{ }^{\circ} \mathrm{C}$ fitted to the Page model

Table 2. Obtained parameters, coefficients of determination $\left(R^{2}\right)$, mean square deviation (MSD) and residual distribution (RD) of the mathematical models fitted to the 'pitaya' peel drying kinetic curves

\begin{tabular}{|c|c|c|c|c|c|c|c|c|}
\hline \multirow{2}{*}{ Model } & \multirow{2}{*}{$\begin{array}{l}\text { Temp. } \\
\left({ }^{\circ} \mathrm{C}\right)\end{array}$} & \multicolumn{4}{|c|}{ Parameters } & \multirow{2}{*}{$\mathbf{R}^{2}$} & \multirow{2}{*}{ MSD } & \multirow{2}{*}{ RD } \\
\hline & & a & C & $K$ & $n$ & & & \\
\hline \multirow{3}{*}{ Page } & 50 & - & - & 0.0016 & 1.2375 & 0.9988 & 0.0158 & $\mathrm{R}$ \\
\hline & 60 & - & - & 0.0025 & 1.2191 & 0.9991 & 0.0139 & $\mathrm{R}$ \\
\hline & 70 & - & - & 0.0025 & 1.2813 & 0.9993 & 0.0113 & $\mathrm{R}$ \\
\hline \multirow{3}{*}{ Henderson \& Pabis } & 50 & 1.0445 & - & 0.0056 & - & 0.9944 & 0.0415 & $\mathrm{R}$ \\
\hline & 60 & 1.0428 & - & 0.0076 & - & 0.9954 & 0.0388 & B \\
\hline & 70 & 1.0563 & - & 0.0089 & - & 0.9943 & 0.0463 & B \\
\hline \multirow{3}{*}{ Two-term exponential } & 50 & 0.0018 & - & 2.9080 & & 0.9918 & 0.0342 & $\mathrm{R}$ \\
\hline & 60 & 0.0034 & - & 2.0336 & & 0.9932 & 0.0312 & $\mathrm{R}$ \\
\hline & 70 & 0.0017 & - & 4.7385 & & 0.9908 & 0.0364 & B \\
\hline \multirow{3}{*}{ Logarithmic } & 50 & 1.2206 & -0.2018 & 0.0039 & - & 0.9993 & 0.0124 & $\mathrm{R}$ \\
\hline & 60 & 1.1564 & -0.1338 & 0.0059 & - & 0.9990 & 0.0145 & B \\
\hline & 70 & 1.1628 & -0.1259 & 0.0070 & - & 0.9979 & 0.2222 & B \\
\hline \multirow{3}{*}{ Newton } & 50 & - & - & 0.0052 & - & 0.9920 & 0.0401 & $B$ \\
\hline & 60 & - & - & 0.0072 & - & 0.9937 & 0.0376 & $\mathrm{R}$ \\
\hline & 70 & - & - & 0.0081 & - & 0.9910 & 0.0458 & $\mathrm{~B}$ \\
\hline
\end{tabular}

B - Biased; R - Random 
The drying curves were influenced by the temperature (Figure 2). There was a gradual reduction in the dehydration time as the drying air temperature increased, a behavior frequently reported in residues of vegetal products, such as 'Mulungu' bark, pineapple residues and mango residues (Alexandre et al., 2013; André et al., 2014; Martins et al., 2014). This behavior is due to the higher water removal rate from the product because of the higher moisture gradient between the product and the air, caused by the increment in temperature (Sousa et al., 2011). The peels showed initial moisture content of $93.38 \%$ (w.b.) and reached drying times of 500, 415 and $385 \mathrm{~min}$ at temperature of 50,60 and $70{ }^{\circ} \mathrm{C}$, with moisture contents of $5.39,5.27$ and $4.40 \%$ (w.b.) (Table 3), respectively.

There was a reduction in the moisture content with the increase in drying temperature, which was already expected, since increments in temperature promote increments in water diffusion during the dehydration process. The moisture content was below the value allowed by the Brazilian Legislation (Brasil, 2005a) for products that are dried and processed in the form of flour, which is at most 15\%, and close to that found by Yusof et al. (2012) for lyophilized pitaya, 5.77\%.

Physical and chemical characterizations of pitaya peel powder obtained by drying at temperatures of 50,60 and $70{ }^{\circ} \mathrm{C}$ are presented in Table 3.

Water activity $\left(\mathrm{a}_{\mathrm{w}}\right)$ decreased with the increment in drying temperature, but there was no statistical difference $(\mathrm{p}>0.05)$ between the powders produced at temperatures of 60 and $70^{\circ} \mathrm{C}$. The low water activity found in pitaya peel powders is important, because it gives greater stability to the dehydrated product during storage, thus increasing its shelf life. Water activity values ranged between 0.310 and 0.360 , and are inferior to that reported by Cazarin et al. (2014) in passion fruit peel flour dehydrated in forced-air oven at temperature of $50{ }^{\circ} \mathrm{C}$, equal to 0.430 .

Increment in dehydration temperature resulted in substantial decrease of total titratable acidity (TTA), approximately $15.73 \%$, probably related to thermal degradations of organic acids along the drying. Since TTA encompasses all acids present in the product, any loss in some of the constituent acids is assumed to interfere with this result. Despite that, the TTA of pitaya powder was high, with values above $2 \%$, which is interesting because it guarantees an acid characteristic of the product after dilution, maintaining microbiological stability.

Increment in drying temperature led to increase in $\mathrm{pH}$ values, especially related to the reduction of TTA, since these parameters are inversely correlated, i.e., the lower the TTA, the higher the $\mathrm{pH}$. This is due to the reduction of $\mathrm{H}^{+}$ions in solution, due to the degradation of organic acids. The $\mathrm{pH}$ values of pitaya peel powder remained above the range considered as safe to maintain microbiological stability, delimiting its development, which corresponded to $\mathrm{pH}$ values $<4.5$. However, one should consider that low $\mathrm{a}_{\mathrm{w}}$ values guarantee microbiological stability along the storage period.

Ascorbic acid content increased with the increment in drying temperature, which may be related to the reductions in the dehydration times as the temperature increased, leading to lower exposure of the sample to the drying process and a greater retention of the content of this micronutrient. Pitaya peel powders were not considered as potential sources of ascorbic acid, and 279 to $395 \mathrm{~g}$ of the product were necessary to meet the recommended daily intake for an adult, which is $45 \mathrm{mg} \mathrm{day}^{-1}$ (Brasil, 2005b).

Reducing sugars significantly decreased with the increments in dehydration temperature. This behavior is possibly due to the Maillard reaction, which culminates in degradation of reducing sugars when they complex with free amino acids, synthesizing dark-colored products. Although reducing sugars exhibited a considerable reduction, around $35 \%$, the values remained close to those of powders of residues from fruits, such as guava (5.21\%) and passion fruit (8.30\%) (Uchoa et al., 2008).

Increment in drying temperature led to significant reduction of betacyanins and betaxanthins in pitaya peels, which is consistent with Mello et al. (2015), who reported that betalains can be degraded during the exposure to high temperatures. Increments of $20{ }^{\circ} \mathrm{C}$ were sufficient to considerably reduce betalains, by 66.71 and $44.54 \%$ for betacyanins and betaxanthins, respectively, suggesting that the first pigment is more sensitive to the dehydration process.

The temperature of $50^{\circ} \mathrm{C}$ would be the most adequate for pitaya peel drying, because it retains high concentrations of betacyanins and betaxanthins, which highlights its potential to be used by industries to replace artificial dyes, promoting benefits to health, such as antioxidant activity. Ghokale \& Lele (2014) studied the effect of drying at temperatures from 50 to $120{ }^{\circ} \mathrm{C}$ on betalain retention and found that, at lower temperatures, there was lower degradation of these constituents, corroborating the results of the present study.

It is noted that $\mathrm{L}^{\star}$ values increased with the increment in temperature, which may be related to the faster drying at higher temperatures, leading to lower darkening. Oliveira et al. (2016)

Table 3. Physical and chemical characterization of 'pitaya' peel drying at temperatures of 50,60 and $70{ }^{\circ} \mathrm{C}$

\begin{tabular}{|c|c|c|c|}
\hline \multirow{2}{*}{ Parameters } & \multicolumn{3}{|c|}{ Temperature $\left({ }^{\circ} \mathrm{C}\right)$} \\
\hline & 50 & 60 & 70 \\
\hline Moisture content (\% w.b.) & $5.39 \pm 0.20 a$ & $5.27 \pm 0.30 a$ & $4.40 \pm 0.12 b$ \\
\hline Water activity $\left(\mathrm{a}_{\mathrm{w}}\right)$ & $0.353 \pm 0.01 \mathrm{a}$ & $0.319 \pm 0.01 b$ & $0.318 \pm 0.01 b$ \\
\hline $\mathrm{pH}$ & $5.06 \pm 0.01 c$ & $5.09 \pm 0.01 b$ & $5.13 \pm 0.02 \mathrm{a}$ \\
\hline Total titratable acidity (\% citric acid) & $2.67 \pm 0.03 a$ & $2.54 \pm 0.03 b$ & $2.25 \pm 0.05 c$ \\
\hline Ascorbic acid $\left(\mathrm{mg} 100 \mathrm{~g}^{-1}\right)$ & $11.38 \pm 0.01 c$ & $14.79 \pm 0.01 b$ & $16.11 \pm 0.50 \mathrm{a}$ \\
\hline Reducing sugars (\% glucose) & $8.56 \pm 0.10 a$ & $6.28 \pm 0.03 b$ & $5.56 \pm 0.06 c$ \\
\hline Betacyanins (mg $100 \mathrm{~g}^{-1}$ ) & $51.81 \pm 0.00 a$ & $24.39 \pm 0.01 b$ & $17.25 \pm 0.00 \mathrm{c}$ \\
\hline Betaxanthins (mg $100 \mathrm{~g}^{-1}$ ) & $63.50 \pm 0.01 \mathrm{a}$ & $44.73 \pm 0.00 b$ & $35.22 \pm 0.00 c$ \\
\hline Luminosity $\left(L^{\star}\right)$ & $48.76 \pm 0.08 c$ & $56.81 \pm 0.08 b$ & $59.29 \pm 0.10 a$ \\
\hline Redness $\left(+a^{*}\right)$ & $16.80 \pm 0.04 a$ & $11.74 \pm 0.02 b$ & $11.27 \pm 0.03 c$ \\
\hline Yellowness $\left(+b^{\star}\right)$ & $17.80 \pm 0.13 c$ & $27.17 \pm 0.20 b$ & $28.99 \pm 0.17 \mathrm{a}$ \\
\hline
\end{tabular}

Means followed by the same letter in the rows do not differ statistically by Tukey test at 0.05 probability level 
observed this behavior in the drying of 'baru' (Dipteryx alata Vogel), at temperatures from 60 to $100{ }^{\circ} \mathrm{C}$, and found that the increase of temperature resulted in powders with higher $\mathrm{L}^{*}$.

The values of $+a^{*}$ decreased with the increment of temperature, indicating that as temperature increased, the pink color tending to violet-red was degraded to shades of yellow (Herbach et al., 2006). For $+b^{\star}$ values, a considerable increase occurred with the increment in temperature. Similar behavior was reported by Nunes et al. (2017), studying the influence of drying temperature $\left(50-70{ }^{\circ} \mathrm{C}\right)$ on pineapple residue.

\section{Conclusions}

1. Among the fitted mathematical models, Page was selected as the most adequate to predict the studied phenomenon.

2. Increment in drying temperature caused increase in $\mathrm{pH}$, ascorbic acid, luminosity and yellowness, and reduction in reducing sugars, moisture content, water activity, acidity, betacyanins, betaxanthins and redness.

3. For leading to higher quantity of betalains and conservation of the characteristic color, the temperature of $50{ }^{\circ} \mathrm{C}$ was considered as the most adequate for the drying of 'pitaya' peels to produce powders, due to the higher natural coloring potential.

\section{Literature Cited}

Alexandre, H. V.; Silva, F. L. H. da; Gomes, J. P.; Silva, O. S. da; Carvalho, J. P. D.; Lima, E. E. de. Cinética de secagem do resíduo de abacaxi enriquecido. Revista Brasileira de Engenharia Agrícola e Ambiental, v.17, p.640-646, 2013. https://doi. org/10.1590/S1415-43662013000600010

André, A. M. M. C. N.; Castro, D. S. de; Almeida, R. D.; Moreira, I. dos S. Análise e comparação dos modelos matemáticos da secagem do resíduo de manga 'Tommy Atkins'. Revista Verde de Agroecologia e Desenvolvimento Sustentável, v.9, p.1-6, 2014.

Bakar, S. C. E. J.; Muhammad, K.; Hashim, D. M.; Adzahan, N. Spraydrying optimization for red pitaya peel (Hylocereus polyrhizus). Food Bioprocess Technology, v.6, p.1332-1342, 2013. https://doi. org/10.1007/s11947-012-0842-5

Brasil. Agência Nacional de Vigilância Sanitária. Regulamento técnico para produtos de cereais, amidos, farinhas e farelos. Resolução RDC n.263, de 22 de setembro de 2005. Brasília: Diário Oficial da União, 2005a.

Brasil. Agência Nacional de Vigilância Sanitária. Resolução RDC n.269, de 22 de setembro de 2005. Regulamento Técnico sobre a ingestão diária recomendada (IDR) de proteína, vitaminas e minerais. Brasília: Diário Oficial da União, 2005b.

Cazarin, C. B. B.; Silva, J. K. da; Colomeu, T. C.; Zollner, R. de L.; Maróstica Júnior, R. M. Capacidade antioxidante e composição química da casca de maracujá (Passiflora edulis). Ciência Rural, v.44, p.1699-1704, 2014. https://doi.org/10.1590/01038478 cr20131437

Fernandes, L. M. de S.; Vieites, R. L.; Cerqueira, R. C.; Braga, C. de L.; Sirtoli, L. F.; Amaral, J. L. do. Características pós-colheita em frutos de pitaya orgânica submetida a diferentes doses de irradiação. Revista Biodiversidade, v.9, p.15-22, 2010.
Ghokale, S. V.; Lele, S. S. Betalain content and antioxidant activity of Beta vulgaris: Effect of hot air convective drying and storage. Journal of Food Processing and Preservation, v.38, p.585-590, 2014. https://doi.org/10.1111/jfpp.12006

Gonçalves, J. Q.; Silva, M. A. P. da; Plácido, G. R.; Caliari, M.; Silva, R. M.; Moura, L. C.; Souza, D. G. Secagem da casca e polpa da banana verde (Musa acuminata): Propriedades físicas e funcionais da farinha. Global Science and Technology, v.9, p.62-72, 2016.

Goneli, A. L. D.; Corrêa, P. C.; Afonso Júnior, P. C.; Oliveira, G. H. H. de. Cinética de secagem dos grãos de café descascados em camada delgada. Revista Brasileira de Armazenamento, v.11, p.64-73, 2009.

Goneli, A. L. D.; Corrêa, P. C.; Magalhães, F. E. de A.; Baptestini, F. M. Contração volumétrica e forma dos frutos de mamona durante a secagem. Acta Scientiarum. Agronomy, v.33, p.1-8, 2011. https:// doi.org/10.4025/actasciagron.v33i1.4629

Herbach, K. M.; Stintzing, F. C.; Carle, R. Stability and color changes of thermally treated betanin, phyllocactin, and hylocerenin solutions. Journal of Agricultural and Food Chemistry, v.54, p.390-398, 2006. https://doi.org/10.1021/jf051854b

IAL - Instituto Adolfo Lutz. Métodos físico-químicos para análise de alimentos. 4.ed. São Paulo: IAL, 2008. 1020p.

Liaotrakoon, W.; Clercq, N. de; Hoed, V. van; Dewettinck, K. Dragon fruit (Hylocereus spp.) seed oils: Their characterization and stability under storage conditions. Journal of the American Oil Chemists' Society, v.90, p.207-215, 2013. https://doi.org/10.1007/ s11746-012-2151-6

Lim, S. D.; Yusof, Y. A.; Chin, N. L.; Talib, R. A.; Endan, J.; Azziz, M. G. Effect of extraction parameters on the yield of betacyanins from pitaya fruit (Hylocereus polyrhyzus) pulps. Journal of Food, Agriculture and Environment, v.9, p.158-162, 2011.

Lima, C. A. de; Faleiro, F. G.; Junqueira, N. T. V.; Cohen, K. de O.; Guimarães, T. G. Características físico-químicas, polifenóis e flavonoides amarelos em frutos de espécies de pitaias comerciais e nativas do cerrado. Revista Brasileira de Fruticultura, v.35, p.565570, 2013. https://doi.org/10.1590/S0100-29452013000200027

Martins, J. J. A.; Marques, J. I.; Santos, D. da C.; Rocha, A. P. T. Modelagem matemática da secagem de cascas de mulungu. Bioscience Journal, v.30, p.1652-1660, 2014.

Mello, F. R. de; Bernardo, C.; Dias, C. O.; Gonzaga, L.; Amante, E. R.; Fett, R.; Candido, L. M. B. Antioxidant properties, quantification and stability of betalains from pitaya (Hylocereus undatus) peel. Ciência Rural, v.45, p.323-328, 2015. https://doi. org/10.1590/0103-8478cr20140548

Mendonça, A. P.; Sampaio, P. de T. B.; Almeida, F. de A. C.; Ferreira, R. F.; Novais, J. M. Determinação das curvas de secagem das sementes de andiroba em secador solar. Revista Brasileira de Engenharia Agrícola e Ambiental, v.19, p.382-387, 2015. https:// doi.org/10.1590/1807-1929/agriambi.v19n4p382-387

Nunes, J. S.; Lins, A. D. F.; Gomes, J. P.; Silva, W. P. da; Silva, F. B. da. Influência da temperatura de secagem nas propriedades físicoquímica de resíduos abacaxi. Revista Agropecuária Técnica, v.1, p.41-46, 2017. https://doi.org/10.25066/agrotec.v38i1.29991

Oliveira, D. E. C. de; Resende, O.; Costa, L. M. Efeitos da secagem na coloração dos frutos de baru (Dipteryx alata Vogel). Revista Agro@mbiente, v.10,p.364-370, 2016.

Perez, L. G.; Oliveira, F. M. N. de; Andrade, J. S.; Moreira Filho, M. Cinética de secagem da polpa cupuaçu (Theobroma grandiflorum) pré desidratada por imersão-impregnação. Revista Ciência Agronômica, v.44, p.102-106, 2013. https://doi.org/10.1590/ S1806-66902013000100013 
Silva, F. de. A. S.; Azevedo, C. A. V. de. The Assistat Software Version 7.7 and its use in the analysis of experimental data. African Journal of Agricultural Research, v.11, p.3733-3740, 2016. https://doi.org/10.5897/AJAR2016.11522

Sousa, K. A. de; Resende, O.; Chaves, T. H.; Costa, L. M. Cinética de secagem do nabo forrageiro (Raphanus sativus L.). Revista Ciência Agronômica, v.42, p.883-892, 2011. https://doi. org/10.1590/S1806-66902011000400009
Uchoa, A. M. A.; Costa, J. M. C. da; Maia, G. A.; Silva, E. M. C.; Carvalho, A. de F. F. U.; Meira, T. R. Parâmetros físico-químicos, teor de fibra bruta e alimentar de pós alimentícios obtidos de resíduos de frutas tropicais. Segurança Alimentar e Nutricional, v.15, p.58-65, 2008.

Yusof, Y. A.; Mohd Salleh, F. S.; Chin, N. L.; Talib, R. A. The drying and tabletting of pitaya power. Journal of Food Process Engineering, v.35, p.763-771, 2012. https://doi.org/10.1111/ j.1745-4530.2010.00625.x 